\title{
Comparison of 2-compartment, 3-compartment and stack designs for electrodialytic removal of heavy metals from harbour sediments
}

Pedersen, Kristine B.; Ottosen, Lisbeth M.; Jensen, Pernille Erland; Lejon, Tore

Published in:

Electrochimica Acta

Link to article, DOI:

10.1016/j.electacta.2014.12.003

Publication date:

2015

Document Version

Peer reviewed version

Link back to DTU Orbit

Citation $(A P A)$ :

Pedersen, K. B., Ottosen, L. M., Jensen, P. E., \& Lejon, T. (2015). Comparison of 2-compartment, 3compartment and stack designs for electrodialytic removal of heavy metals from harbour sediments. Electrochimica Acta, 181, 48-57. https://doi.org/10.1016/j.electacta.2014.12.003

\section{General rights}

Copyright and moral rights for the publications made accessible in the public portal are retained by the authors and/or other copyright owners and it is a condition of accessing publications that users recognise and abide by the legal requirements associated with these rights.

- Users may download and print one copy of any publication from the public portal for the purpose of private study or research.

- You may not further distribute the material or use it for any profit-making activity or commercial gain

- You may freely distribute the URL identifying the publication in the public portal 


\title{
Comparison of 2-compartment, 3-compartment and stack designs for electrodialytic removal of heavy metals from harbour sediments
}

Kristine B. Pedersen ${ }^{a}$, Lisbeth M. Ottosen ${ }^{b 1}$, Pernille E. Jensen ${ }^{b}$ and Tore Lejon ${ }^{a}$ *

*Corresponding author: e-mail tore.lejon@uit.no; tel. +47 776 44736; fax. +47 77644765

a Department of Chemistry, University of Tromsø, The Arctic University of Norway, Postbox 6050 Langnes, N-9037 Tromsø, Norway.

b Arctic Technology Centre, Department of Civil Engineering, Technical University of Denmark, Building 118, 2800 Lyngby, Denmark

\begin{abstract}
Comparisons of cell and stack designs for the electrodialytic removal of heavy metals from two harbour sediments, were made. Multivariate modelling showed that sediment properties and experimental set-ups had the highest influence on the heavy metal removal indicating that they should be modelled and analysed separately. Clean-up levels of $\mathrm{Cu}, \mathrm{Pb}$ and $\mathrm{Zn}$ were significantly higher for the cell designs, implying that longer time and relatively more electric charge and energy would be necessary to achieve similar clean-up levels in the stack design experiments.

In the studied experimental domain, the optimal current density for the 2- and 3-compartment cells was $0.12 \mathrm{~mA} / \mathrm{cm}^{2}$ (center value) removing the highest quantity of $\mathrm{Cu}, \mathrm{Pb}$ and $\mathrm{Zn}$ per Wh. The highest percentages removed were $82 \% \mathrm{Cu}, 81 \% \mathrm{~Pb}$ and $92 \% \mathrm{Zn}$ were however achieved at higher current density. For the stack experiments conducted at same electric charge per unit sediment, energy consumption was a magnitude higher and the highest clean-up levels were $21 \% \mathrm{Cu}, 42 \% \mathrm{~Pb}$ and $73 \% \mathrm{Zn}$.
\end{abstract}

Keywords: Remediation, heavy metals, harbour sediments, electrokinetics, electrodialysis

\footnotetext{
${ }^{1}$ ISE member
} 


\section{Introduction}

Electrodialytic remediation (EDR) is based on applying an electric field of low current to the contaminated material and is among the electrokinetic remediation methods used for removing heavy metals from contaminated materials. The electric field initiates electrolysis reactions at the electrode, producing protons at the anode and hydroxyl ions at the cathode. Since the effective ionic mobility of protons is higher than that of hydroxyl ions, an acidic front prevails in the contaminated material [1] and heavy metals are subsequently desorbed, mobilised and transported by electromigration towards the cathode. The rate of acidification of the contaminated material depends on its physical and chemical properties; a high buffering capacity in soil will, for instance, retard the acidification as may high levels of organic species and salts [2-4].

EDR controls the formation and progress of the acidic and alkaline fronts by making use of ion exchange membranes, which physically separate the contaminated material from the electrodes and circulating electrolytes. In addition, they control the transport of ions between the contaminated material and electrolytes, preventing the introduction of protons and hydroxyl ions from the electrolysis reactions into the contaminated material. Acidification of the contaminated material is however still achieved, mainly due to water splitting at the anion exchange membrane [5] and the hydroxyl ions produced are transported across the membrane to the anolyte while the protons advance towards the cathode (figure 1).

EDR has been successfully used for the removal of heavy metals from different contaminated solid materials such as soil, harbour sediments, wood, fly ash and sewage sludge [6-10]. During the last decade, the majority of EDR studies have been conducted on lab scale using a 3-compartment design (figure 1), consisting of a centre compartment with the polluted material and two adjoining compartments in which electrolytes are continuously circulated. 
Experimental variables shown to have significant effect on the heavy metal removal in this design include current density, remediation time and liquid-solid (L/S) ratio of the contaminated material [10-12]. In addition, several studies have shown that applying a stirred rather than a stationary set-up significantly improves the removal of heavy metals from soil [13], harbour sediment [14] and fly ash [15].

Recently, a new design for EDR lab-scale experiments, consisting of a 2-compartment cell, has been developed and patented at The Technical University of Denmark. The polluted material compartment is adjoined by one compartment in which electrolyte is circulated. A cation exchange membrane separates the two compartments and ensures that desorbed elements from the contaminated material are transported to the electrolyte while preventing hydroxyl ions produced in the electrolysis reactions from entering the contaminated material compartment. The anode is placed directly in the polluted material, leading to acidification due to the direct supply of protons. Few studies have been conducted in the 2-compartment cell and the influence of experimental variables on EDR in this design has not been as well documented as for the 3-compartment cells. A recent study, however, established that the acidification time was significantly reduced, the final $\mathrm{pH}$ was lower and lower voltages were observed in the 2-compartment compared to the 3-compartment cell. In addition the higher conductivity in the 2-compartment cell was attributed to the direct introduction of protons to the suspension [16].

An EDR stack design for bench-scale experiments was introduced by Jensen et al. [17] for improving the recycling potential of contaminated fly-ash by reducing the leachability of heavy metals. The stack, consisting of alternating feed- and concentrate-compartments, was designed based on the principles of the 3-compartment cell with the aim of continuous treatment of larger quantities of fly-ash and for the later scaling-up to pilot-plant [18]. The polluted material in suspension is continuously circulated in the feed compartments, while 
concentrate liquid is continuously circulated in the adjacent concentrate compartments. Ionexchange membranes separate the feed- and concentrate-compartments (figure 1) and control the transport of ions between the compartments. Acidification of the polluted material is ensured by water splitting at the anion exchange membrane and the subsequent accumulation of protons in the feed compartments. The desorbed heavy metals are transported by electromigration from the feed- to the concentrate compartments.

\section{Figure 1}

Direct comparisons of the above cell- and stack designs have not yet been undertaken.

Multivariate analysis provides a valuable tool for such a comparison and is based on statistical experimental design and evaluation of the results, e.g. by Projections onto Latent Structures (PLS).

PLS is a multivariate statistical tool for evaluating the experimental variable importance within the studied experimental domains. Among the advantages of PLS is that it copes with colinearity between variables and provides plots of the data compressed to fewer dimensions than the original dataset [19-21]. In this respect, PLS has proven a reliable tool for assessing the comparative experimental variable importance as well as for predicting experimental conditions for specified remediation objectives for the electrodialytic removal of heavy metals from harbour sediments [22, 23].

In this study PLS was used to model the quantitative relation between a descriptor matrix, $\mathrm{X}$, consisting of the experimental variables and a response matrix, $\mathrm{Y}$, consisting of the heavy metal clean-up levels. Object points in each of the $\mathrm{X}$ and $\mathrm{Y}$ matrices are projected down to a PLS component. For each PLS dimension the PLS scores of the Y-matrix are calculated to have a maximum correlation to the scores of the X-matrix. New PLS components are iteratively introduced until the systematic variation in the Y-matrix has been exhausted [19, 20]. 
The main objective of this study was to compare the different experimental set-ups for two harbour sediments, thus providing a foundation for later scaling-up. The comparison focused on the two experimental variables current density and remediation time for the three EDR designs: 2-compartment cell, 3-compartment cell and stack, as well as clean-up levels and energy consumption. Since EDR of harbour sediments in the stack has not previously been reported, a more elaborate analysis for understanding the EDR processes was included in the study.

\section{Experimental}

\subsection{Experimental sediments}

Sediments from Sisimiut, Greenland and Hammerfest, Norway were sampled from the top 10 cm of the seabed using a Van Veen grab and were kept frozen during transport and stored in a freezer until analysed or treated.

Since the EDR stack could not treat sediment suspensions with grain sizes above $1 \mathrm{~mm}$, the sediments were sieved through a $1 \mathrm{~mm}$ sieve prior to use to enable comparison of the different designs/set-ups.

\subsection{Sediment analyses}

Major elements and heavy metal concentrations (Al, Ca, Fe, K, Mg, Mn, Na, V, Cr, Cu, Ni, $\mathrm{Pb}, \mathrm{Zn}$ ) were measured based on digestion (Danish standard DS259). Sediment dried at $105^{\circ} \mathrm{C}$ (1.0g) and $\mathrm{HNO}_{3}(9 \mathrm{M}, 20 \mathrm{~mL})$ were autoclaved $\left(200 \mathrm{kPa}, 120^{\circ} \mathrm{C}, 30\right.$ minutes) and solid particles were subsequently removed by vacuum filtration through a $0.45 \mu \mathrm{m}$ filter and the liquid was diluted to $100 \mathrm{~mL}$ with distilled water. Metal concentrations in the liquid were measured by Inductively Coupled Plasma - Optical Emission Spectroscopy (ICP-OES). Chloride content was measured by agitating sediment dried at $40^{\circ} \mathrm{C}(10 \mathrm{~g})$ with Millipore water (40mL) for 20 hours on a horizontal shaker. Solid particles were subsequently removed 
by vacuum filtration through a $0.45 \mu \mathrm{m}$ filter and the chloride concentration was measured by ion chromatography.

Carbonate content was measured by treating dried sediment (5g) with $\mathrm{HCl}$ (3M; 20mL) and volumetrically measuring the $\mathrm{CO}_{2}$ developed in a Scheibler apparatus, calibrated with $\mathrm{CaCO}_{3}$. Organic content was based on loss of ignition of dried sediment $\left(2.5 \mathrm{~g}, 550^{\circ} \mathrm{C}, 1\right.$ hour). $p H(\mathrm{KCl})$. Dried sediment $(5 \mathrm{~g})$ was agitated with $\mathrm{KCl}(1 \mathrm{M}, 12.5 \mathrm{~mL})$ for an hour and $\mathrm{pH}$ was subsequently measured using a radiometer analytical electrode.

Wet sieving. A mixture of wet sediment (75g), distilled water $(350 \mathrm{~mL})$ and $\mathrm{Na}_{4} \mathrm{P}_{2} \mathrm{O}_{7} \cdot 10 \mathrm{H}_{2} \mathrm{O}$ $(0.1 \mathrm{M}, 10 \mathrm{~mL})$ was agitated for 24 hours. This slurry was subsequently sieved through a $63 \mu \mathrm{m}$ sieve to determine the fraction above and below $63 \mu \mathrm{m}$.

Sequential extraction was made in four steps based on the improvement of the three-step method [24] described by Standards, Measurements and Testing Program of the European Union. Air-dried sediment (0.5g) was first extracted with acetic acid $(0.11 \mathrm{M}, 20 \mathrm{~mL}, \mathrm{pH})$ for 16 hours; secondly extracted with hydroxylammonium chloride $(0.1 \mathrm{M}, 20 \mathrm{~mL} ; \mathrm{pH} 2)$ for 16 hours; thirdly extracted with hydrogen peroxide $(8.8 \mathrm{M}, 5 \mathrm{~mL})$ for 1 hour, followed by extraction at $85^{\circ} \mathrm{C}$ for 1 hour, then evaporation of liquid at $85^{\circ} \mathrm{C}$ and subsequently the cooled solid fraction was extracted with ammonium acetate (1M, 25mL, $\mathrm{pH} 2)$ for $16 \mathrm{~h}$; and a fourth digestion of the remaining solid particles was performed (as described above).

pH dependent extraction experiments were made by agitating 8 samples of dried sediment (5g) with $\mathrm{HNO}_{3}(25 \mathrm{~mL})$ in varying concentrations (0.01M-1M). Extractions with distilled water were made as a reference. All the extractions were agitated for a week on a horizontal shaker. Subsequently samples settled for 15 minutes and the $\mathrm{pH}$ was measured. Solid particles were separated from the sediment suspensions by vacuum filtration through a $45 \mu \mathrm{m}$ filter and digestion (as described above) of the dried solid particles was conducted. 


\subsection{EDR experiments}

\subsubsection{Materials}

The 2-compartment and 3-compartment cells used in the study were designed (figure 1) using the same materials and sizes; the 2-compartment cell not containing an electrolyte compartment or anion exchange membrane. The cell compartments were manufactured from Plexiglas and the dimensions were: length of electrolyte compartments $3.5 \mathrm{~cm}$; length of sediment suspension compartment $10 \mathrm{~cm}$; inner diameter of all compartments $8 \mathrm{~cm}$. Ion exchange membranes were from Ionics (anion exchange membrane 204 SZRA B02249C and cation exchange membrane CR67 HUY N12116B). The electrolyte used was $\mathrm{NaNO}_{3}(0.01 \mathrm{M})$ adjusted to $\mathrm{pH} 2$ by $\mathrm{HNO}_{3}(7 \mathrm{M})$. The electrolyte liquids (350 mL) were circulated between external glass bottles and the electrolyte compartments via Pan World pumps with flow rates of $30 \mathrm{~mL} / \mathrm{min}$. Platinum coated titanium electrodes were used in each electrolyte compartment and a power supply (Hewlett Packard E3612A) maintained a constant DC current. The sediment suspension was stirred by a RW11 Basic lab-egg (IKA 2830001) with a stirrer consisting of plastic flaps $(4 \mathrm{~cm} \times 0.5 \mathrm{~cm})$ fastened to a glass rod.

After the EDR experiments the sediment suspensions were gravity filtered and the heavy metal concentration in the liquid and solids from the suspension were measured. The stirrer, membranes and electrodes were rinsed in $\mathrm{HNO}_{3}(5 \mathrm{M})$ overnight and the heavy metal concentrations in the rinsing liquids along with the electrolyte liquids were measured by ICPOES.

Spacers, ion-exchange membranes and electrodes were assembled into an EDR stack based on the electrodialysis cell design by Jurag Separation A/S. The stack used in the present study consisted of 5 feed spacers with alternating concentrate spacers. The feed and concentrate spacers were separated by alternating cation and anion exchange membranes resulting in 5 
feed compartments separated by concentrate compartments (figure 1). At each end of the stack an electrode compartment was separated from the adjacent concentrate compartment with ion-exchange membranes. Each feed spacer was $5 \mathrm{~mm}$ wide and had an inlet at the bottom and an outlet at the top, both $3 \mathrm{~mm}$ wide, enabling sediment with grain sizes $<1 \mathrm{~mm}$ to pass through the feed compartment without clogging. The concentrate spacer was $0.6 \mathrm{~mm}$ wide and also had an inlet at the bottom and an outlet at the top. Each ion-exchange membrane had a surface area of $530 \mathrm{~cm}^{2}$, equal to the compartment surface.

External plastic containers initially contained 3L of electrolyte ( $\left.\mathrm{NaNO}_{3}, 0.01 \mathrm{M}\right), 3 \mathrm{~L}$ concentrate $\left(\mathrm{NaNO}_{3}, 0.01 \mathrm{M}\right)$ and $6 \mathrm{~L}$ sediment suspension and circulation of the individual liquids/suspension were ensured by external pumps. Electrolyte liquids from the cathode and anode compartments were mixed in the external electrolyte container. Circulation of the sediment suspension ensured mixing without need for stirring in the external suspension container.

After the EDR experiments the sediment suspensions were gravitational filtered and the heavy metal concentration in the suspension liquid and solids along with the concentrate and electrolyte liquids were measured by ICP-OES. The feed compartments of the stack were rinsed with distilled water and the concentrate and electrolyte compartments were first rinsed with $\mathrm{HNO}_{3}(0.1 \mathrm{M})$ and subsequently with distilled water.

\subsubsection{Experimental design}

Previous EDR experiments found that PLS model predictability and reliability increased when time after acidification was included as a parameter rather than the total duration of the experiments. Acidification time in this study is the time for achieving $\mathrm{pH} 4$ in the sediment suspension. Time after acidification is accordingly the time the experiment ran after reaching pH 4 in the sediment suspension. 
The same current densities and liquid/solid (L/S) ratios were used in the comparable cell- and stack experiments. The EDR treatment time in the stack experiments does not equal the experimental duration, since only approximately $1 / 5$ of the sediment resides in the stack at any given time. However, larger quantities of sediment were still treated in the stack experiments and therefore the equivalent electrical charge per unit of dried sediment was used for the comparison between the different set-ups.

Treatment time was calculated using the formula:

$\left(I_{c} \times t_{c}\right) / m_{c}=\left(I_{s} \times t_{s}\right) / m_{s}$

where $I$ is the current (A), $t$ is the effective EDR treatment time (h) and $m$ the mass (g) of dry sediment; the $c$ signifies cell and $s$ signifies stack. The remediation time after acidification listed in table 1 is based on the treatment times in the cell experiments; the actual experimental times in the stack were lower (given in brackets in the table).

In all experiments the $\mathrm{L} / \mathrm{S}$ ratio of the sediment suspension was $6 \mathrm{ml} / \mathrm{g}$, using distilled water as suspension liquid and the stirring rate in the cell experiments was 1,300rpm.

9 experimental designs were made to test the comparative influence of the experimental variables. The continuous variables were current density and remediation time after acidification. The discrete variables included two sediments and the three experimental setups. All of the nine experimental designs included 3 variables and were designed as $2^{3-1}$ fractional factorial designs consisting of 4 experiments based on a complete $2^{2}$ factorial design and an additional 3-4 experiments representing centre point(s) of the continuous variables.

In experiments 18, 19 and 22, conducted in the stack, sampling of the sediment suspension, electrolyte liquid and concentrate liquid were made 8 times during each experiment providing more data for modelling and data treatment. 
The experimental designs are given in table 1.

Table 1: Experimental settings. The design parameter time after acidification was based on the duration in cell experiments; electrical charge per mass unit was used to adjust the true duration of the stack experiments. The true duration times for the stack experiments (no. 16-22) are given in brackets.

\begin{tabular}{|c|c|c|c|c|}
\hline Experiment & Sediment & $\begin{array}{l}\text { Current } \\
\text { density } \\
\left(\mathrm{mA} / \mathrm{cm}^{2}\right) \\
\end{array}$ & $\begin{array}{l}\text { Time after } \\
\text { acidification } \\
\text { (h) }\end{array}$ & Set-up \\
\hline 1 & Hammerfest & 0.04 & 48 & 3-compartment \\
\hline 2 & Sisimiut & 0.2 & 48 & 3-compartment \\
\hline 3 & Sisimiut & 0.04 & 278 & 3-compartment \\
\hline 4 & Hammerfest & 0.2 & 278 & 3-compartment \\
\hline 5 & Hammerfest & 0.12 & 163 & 3-compartment \\
\hline 6 & Sisimiut & 0.12 & 163 & 3-compartment \\
\hline 7 & Sisimiut & 0.12 & 163 & 3-compartment \\
\hline 8 & Sisimiut & 0.04 & 48 & 2-compartment \\
\hline 9 & Hammerfest & 0.2 & 48 & 2-compartment \\
\hline 10 & Hammerfest & 0.04 & 278 & 2-compartment \\
\hline 11 & Sisimiut & 0.2 & 278 & 2-compartment \\
\hline 12 & Hammerfest & 0.12 & 163 & 2-compartment \\
\hline 13 & Hammerfest & 0.12 & 163 & 2-compartment \\
\hline 14 & Sisimiut & 0.12 & 163 & 2-compartment \\
\hline 15 & Sisimiut & 0.12 & 163 & 2-compartment \\
\hline 16 & Hammerfest & 0.04 & $0(0)$ & Stack \\
\hline 17 & Hammerfest & 0.2 & $48(2.5)$ & Stack \\
\hline 18 & Sisimiut & 0.04 & $\begin{array}{l}48(2.5) \\
278(14.5)\end{array}$ & Stack \\
\hline 19 & Sisimiut & 0.2 & $\begin{array}{l}0(0) \\
48(2.5) \\
278(14.5) \\
\end{array}$ & Stack \\
\hline 20 & Hammerfest & 0.12 & $24(1.5)$ & Stack \\
\hline 21 & Hammerfest & 0.12 & $24(1.5)$ & Stack \\
\hline 22 & Sisimiut & 0.12 & $\begin{array}{l}24(1.5) \\
163(8.5)\end{array}$ & Stack \\
\hline 23 & Hammerfest & 0.2 & 0 & 3-compartment \\
\hline 24 & Hammerfest & 0.04 & 48 & 2-compartment \\
\hline 25 & Hammerfest & 0.2 & 0 & 2-compartment \\
\hline 26 & Hammerfest & 0.12 & 24 & 3-compartment \\
\hline 27 & Hammerfest & 0.12 & 24 & 2-compartment \\
\hline
\end{tabular}

The clean-up levels were calculated as the percentage of the given heavy metal removed compared to the initial amount in the sediment. The fraction of heavy metal mobilised in the EDR treatment was calculated as the amount in suspension liquid (filtered), electrolyte 
liquid(s) and concentrate liquid compared to the total amount of heavy metal at the time of sampling.

The power consumption in Wh (E) was calculated as:

$\int_{t=0}^{t} E=V I d t$

where $V$ is the voltage between the electrodes (V), $I$ is the current (A) and $t$ is the remediation time (h).

\subsection{PLS modelling}

In this study SimcaP11 software was used for calculating PLS models based on the experiments in table 1 . The $\mathrm{X}$-matrix consisted of the experimental variables and the Y matrix consisted of the removal efficacies (\%) of the elements in the sediment. In models 1-3, the Ymatrix included the elements $\mathrm{Al}, \mathrm{Ba}, \mathrm{Fe}, \mathrm{K}, \mathrm{Mg}, \mathrm{Mn}, \mathrm{Na}, \mathrm{V}, \mathrm{Cr}, \mathrm{Cu}, \mathrm{Ni}, \mathrm{Pb}$ and $\mathrm{Zn}$; while in models 4-5 the Y-matrix included $\mathrm{Cu}, \mathrm{Pb}$ and $\mathrm{Zn}$. In order to include the discrete variables in the modelling, they were arbitrarily set to -1 or 1 .

To assess the reliability and stability of the calculated PLS models the correlation factor R2Y and predictive power, Q2 were calculated. R2Y is a measure of the fraction of the Y matrix explained by the model and Q2 is an estimate of the reliability of the model calculated by cross-validation. Variable Importance in the Projection (VIP) plots present the importance of each parameter in the model with respect to its correlation to all the responses $(\mathrm{Y})$ and to the projection (X). Hence the VIP plots reflect the relative importance of the model parameters to each other and parameters with VIP values above 1 are considered relevant for explaining the responses. The VIP plots do however not convey the numerical influences of variables, so in order to establish whether a given variable has a positive/negative influence on the model, coefficient plots were used.

\section{Results and Discussion}




\subsection{Sediment characteristics}

The sediment characteristics are summarised in table 2 and both sediments have low buffer capacity and low content of organic matter. For some of the elements ( $\mathrm{Ca}, \mathrm{Pb}, \mathrm{Zn}$ ) there are less deviations in the Hammerfest sediment implying that the sediment from Sisimiut is less homogeneous with respect to these elements. In general, the sediment characteristics appear to be at similar levels in the two sediments.

Table 2: Sediment characteristics.

\begin{tabular}{|c|c|c|c|}
\hline Characteristic & Units & $\begin{array}{l}\text { Hammerfest } \\
\text { sediment }\end{array}$ & $\begin{array}{l}\text { Sisimiut } \\
\text { sediment }\end{array}$ \\
\hline Carbonate & $\%$ & $0.7 \pm 0.1$ & $1.7 \pm 0.6$ \\
\hline Organic matter & $\%$ & $5.3 \pm 0.1$ & $6.4 \pm 0.3$ \\
\hline $\mathrm{pH}$ & & $7.5 \pm 0.02$ & $7.5 \pm 0.05$ \\
\hline Grain size $<63 \mu \mathrm{m}$ & $\%$ & 14.3 & 19.0 \\
\hline Chloride & \multirow{15}{*}{$\mathrm{mg} / \mathrm{kg}$} & $9,200 \pm 840$ & $7,950 \pm 470$ \\
\hline $\mathrm{Al}$ & & $7,050 \pm 510$ & $4,003 \pm 375$ \\
\hline $\mathrm{Ba}$ & & $120 \pm 10$ & $80 \pm 10$ \\
\hline $\mathrm{Ca}$ & & $5,100 \pm 480$ & $11,400 \pm 2,800$ \\
\hline $\mathrm{Fe}$ & & $13,100 \pm 850$ & $9,750 \pm 1,250$ \\
\hline $\mathrm{K}$ & & $2,950 \pm 100$ & $1,430 \pm 140$ \\
\hline $\mathrm{Mg}$ & & $4,830 \pm 280$ & $3,200 \pm 310$ \\
\hline $\mathrm{Mn}$ & & $125 \pm 10$ & $70 \pm 10$ \\
\hline $\mathrm{Na}$ & & $5,400 \pm 530$ & $5,120 \pm 840$ \\
\hline $\mathrm{V}$ & & $37 \pm 9$ & $29 \pm 4$ \\
\hline $\mathrm{Cr}$ & & $28 \pm 2$ & $24 \pm 4$ \\
\hline $\mathrm{Cu}$ & & $77 \pm 25$ & $190 \pm 50$ \\
\hline $\mathrm{Ni}$ & & $19 \pm 2$ & $13 \pm 1$ \\
\hline$\overline{\mathrm{Pb}}$ & & $58 \pm 10$ & $66 \pm 20$ \\
\hline $\mathrm{Zn}$ & & $105 \pm 15$ & $290 \pm 50$ \\
\hline
\end{tabular}

Figure 2 illustrates the dispersion of elements in the different fractions of the two sediments, based on results of the sequential extraction. For the heavy metals of environmental interest, more $\mathrm{Ni}$ and $\mathrm{Pb}$, and less $\mathrm{Cr}, \mathrm{Cu}$ and $\mathrm{Zn}$ are related to the exchangeable and reducible fractions in the Hammerfest sediment than in the Sisimiut sediment, which could result in different EDR removal rates. For the other elements, there is generally a higher potential for mobilisation in the Sisimiut sediment.

Figure 2 
Based on the $\mathrm{pH}$ dependent desorption analyses, the desorption order in the Sisimiut sediment was $\mathrm{Zn}(6)>\mathrm{Ni}(5)>\mathrm{Cr}(3), \mathrm{Cu}(3), \mathrm{Pb}(3)$; while the desorption order in the Hammerfest sediment was $\mathrm{Zn}(5)>\mathrm{Ni}(4)>\mathrm{Cu}(3), \mathrm{Pb}(3)>\operatorname{Cr}(2.5)$. This indicates that in order to ensure mobilisation of Cr, Ni and Zn, the sediment suspension should be more acidic for the Hammerfest sediment than the Sisimiut sediment. Therefore, even though the sediment characteristics appear to be similar, the sequential extractions and $\mathrm{pH}$ desorption orders have revealed that different results of EDR might be expected depending on how the heavy metals are bound in the sediment.

In order to investigate this further, both sediments were included in the PLS models calculated for each of the three set-ups:

Model 1a: 3-compartment cell (experiments 1-7)

Model 1b: 2-compartment cell (experiments 8-15)

Model 1c: EDR stack (experiments 16-22)

The three models had correlation factors, R2Y, in the range $0.59-0.76$ and predictive powers in the range 0.04-0.32, the latter indicating unstable models. This could be due to the limited number of experiments or too large an experimental domain; e.g. dissimilar sediments. This is further accentuated in the VIP plots of the models (figure 3) revealing that the sediment had the highest influence on EDR in all of the three set-ups and hence should be modelled separately.

Figure 3

The two models of the cell experiments predicted higher removal efficiencies of $\mathrm{Ni}$ and $\mathrm{Zn}$ in the Sisimiut sediment, and $\mathrm{Pb}$ in the Hammerfest sediment. The predictions of $\mathrm{Pb}$ and $\mathrm{Zn}$ are in line with the EDR results (table 3) and the results of the sequential extractions (figure 2), i.e. a higher fraction of $\mathrm{Pb}$ was bound in the exchangeable and reducible fractions of the Hammerfest sediment while a higher fraction of Zn was bound to the same fractions in the 
Sisimiut sediment. The removal efficiencies of Ni were similar in the two cell designs which may be due to a more uniform distribution in the two sediments than is the case for $\mathrm{Pb}$ and Zn.

\subsection{Comparison of cell and stack experiments}

\subsubsection{General trends in the EDR experiments}

A summary of the results of the EDR experiments is listed in table 3, details of the results are given in the supplementary material table $\mathrm{A}$ and table $\mathrm{B}^{2}$. Some caution should be exercised in making direct comparisons between the three set-ups, since experiments represent different parts of the experimental domain. It is however possible to observe some general trends and differences between the set-ups.

As expected [16], the acidification time was generally shorter in the 2-compartment than in the 3-compartment cell but the difference in acidification time was small, which is probably related to the low buffer capacities of the sediments. Larger differences may however occur when studying more calcareous sediments. The acidification times in the stack are not directly comparable to the cell design experiments since relatively more electric charge per time unit is supplied in the stack. Electrical charge calculations however, revealed that the stack needed relatively more electrical charge per mass unit to acidify the sediment suspension (table 3). The final $\mathrm{pH}$ was generally lower in the 2-compartment than in the 3-compartment cells, which most likely is due to the direct supply of protons in the 2-compartment cell. The final pH the EDR stack suspension liquid were not as acidic as in the cell experiments (implying that clean-up levels for heavy metals desorbing around or below pH 3 might be poorer than in the cell experiments). This observation could be explained by differences in concentration gradients, differences in membranes and/or differences in the transport of $\mathrm{H}^{+}$in the stack compared to the 2- and 3-compartment cell set-ups. However, the $\mathrm{pH}$ in the electrolyte liquids

\footnotetext{
${ }^{2}$ Supplementary materials are available with the on-line version only at (URL)
} 
of the cell set-ups and the concentrate liquid of the stack were equivalent, ruling out that the concentration gradient of $\mathrm{H}^{+}$was different in the three designs. Another possibility is that relatively more $\mathrm{H}^{+}$was transported through the feed compartments in the stack without affecting the sediment suspension than was the case in the 2- and 3-compartment cell set-ups. This could be an effect of different membranes being used in the stack and cell set-ups (potentially affecting water splitting and transport of ions across the membranes), the shorter distance between the membranes in the stack or the flow rate of the sediment suspension. The energy consumption levels (kWh/kg sediment) were generally lowest in the 2compartment cell, followed by the 3-compartment cell and the highest energy consumption was observed for the stack. Since the current density was held constant in the experiments, the fluctuations in voltage and hence resistance across the EDR compartments/cells was the determining factor for the energy consumption. The 2-compartment cell was expected to have lower resistance than the 3-compartment cell due to the set-up only consisting of one ionexchange membrane and in addition the electrolysis reaction at the anode resulting in higher conductivity of the sediment suspension. This was verified by the lower voltages observed for the 2-compartment cell.

Table 3: Summary of EDR results for the cell and stack experiments. Removal efficiencies are the percentage of metal removed from the original sediment.

\begin{tabular}{|l|l|l|l|l|}
\hline & Sediment & 2-compartment & 3-compartment & Stack \\
\hline \multirow{2}{*}{$\begin{array}{l}\text { Acidification time } \\
\text { (h) }\end{array}$} & Hammerfest & $5-26$ & $25-33$ & $15-16$ \\
\cline { 2 - 5 } $\begin{array}{l}\text { Electric charge for } \\
\text { acidification (C/g } \\
\text { sediment) }\end{array}$ & Sisimiut & $21-31$ & $23-31$ & $8-11$ \\
\cline { 2 - 5 } Final pH & Sisimiut & $3-10$ & $3-12$ & $11-51$ \\
\hline & Hammerfest & $1.5-4.0$ & $3-11$ & $6-32$ \\
\cline { 2 - 6 } & Sisimiut & $1.8-3.2$ & $2.0-3.8$ & $3.4-4.0$ \\
\hline $\begin{array}{l}\text { Energy } \\
\text { consumption } \\
\text { (kWh/kg sediment) }\end{array}$ & Hammerfest & $0.005-0.05$ & $0.01-0.78$ & $0.01-0.0 .60$ \\
\cline { 2 - 5 } Removal efficiencies & Sisimiut & $0.01-0.18$ & $0.01-0.04$ & $0.01-1.23$ \\
\hline $\mathrm{Cr}$ & Hammerfest & $0.2-18.9$ & $3.5-34$ & $0-37$ \\
\hline $\mathrm{Cu}$ & Hammerfest & $0.5-72$ & $0-66$ & $0-46$ \\
\hline $\mathrm{Ni}$ & Hammerfest & $0-45$ & $15-40$ & $0-19$ \\
\hline
\end{tabular}




\begin{tabular}{|l|l|l|l|l|}
\hline $\mathrm{Pb}$ & Hammerfest & $0-81$ & $24-70$ & $0-59$ \\
\hline $\mathrm{Zn}$ & Hammerfest & $0-76$ & $32-72$ & $0-42$ \\
\hline $\mathrm{Cr}$ & Sisimiut & $2-33$ & $2-9$ & $0-5$ \\
\hline $\mathrm{Cu}$ & Sisimiut & $12-82$ & $9-45$ & $0-33$ \\
\hline $\mathrm{Ni}$ & Sisimiut & $16-40$ & $25-36$ & $0-27$ \\
\hline $\mathrm{Pb}$ & Sisimiut & $2-49$ & $0-36$ & $0-30$ \\
\hline $\mathrm{Zn}$ & Sisimiut & $62-92$ & $73-84$ & $0-73$ \\
\hline
\end{tabular}

For both sediments, the highest clean-up levels for $\mathrm{Cr}, \mathrm{Cu}, \mathrm{Ni}, \mathrm{Pb}$ and $\mathrm{Zn}$ were observed in the 2-compartment cell, followed by the 3-compartment cell while the EDR stack had the lowest efficiency.

For the cell experiments with remediation time after acidification $<48 \mathrm{~h}$, it is interesting to note that higher clean-up levels of the heavy metals were observed in the 3-compartment cell for the Hammerfest sediments. These experiments (1 and 23-27) have the same experimental settings and are directly comparable. For experiments of longer remediation time, this trend reversed and higher clean-up levels were observed in the 2-compartment cell. The reason for the difference in trends could be due to removal occurring during acidification being more significant to the total removal when employing shorter remediation times.

\subsubsection{EDR set-ups}

Since the sediment had the highest influence on EDR in each of the three experimental setups, the two sediments were modelled separately. The models of the Hammerfest sediments (model 2) and the Sisimiut sediments (model 3) were based on experiments covering the same part of the experimental domain:

Model 2a/3a: The 2-compartment and 3-compartment cells (experiments 1-15; 23-27)

Model 2b/3c: The 2-compartment cell and the EDR stack (experiments 8,9,11-22,24,25,27) Model 2c/3c: The 3-compartment cell and the EDR stack (experiments 1-3,6,7,16-23,26) The correlation factors and predictive powers of the calculated models (figure 4) indicated mediocre and unstable models, which may be related to the experimental domain covering excessive space, most likely due to the differences related to the set-ups. 


\section{Figure 4}

Models 1 and 2 revealed that to achieve a better understanding of the removal efficiencies of elements from the sediments in the three different experimental set-ups; each sediment and each experimental set-up should be modelled separately. The models however provided a general overview of trends in the removal of elements from the two sediments in the three experimental set-ups.

To assess variable importance in the removal of $\mathrm{Cu}, \mathrm{Pb}$ and $\mathrm{Zn}$ from each sediment, in each of the three experimental set-ups, 6 new PLS models were calculated. The models for the Hammerfest sediments (model 4) and the Sisimiut sediments (model 5) were based on all experiments and included:

Model 4a/5a The 2-compartment cell experiments (experiments 8-15,24,25,27)

Model 4b/5b The 3-compartment cell experiments (experiments 1-7,23,26)

Model 4c/5c The EDR stack experiments (experiments 16-22)

The correlation factors of the cell experiments for the Hammerfest sediment (models $4 \mathrm{a}$ and 4b) were 0.95-0.98 and the predictive powers were 0.89-0.97, i.e. good and stable models. The correlation factors for the Sisimiut sediment were 0.73-0.77 and predictive powers of 0.45-.070; the lower values compared to the Hammerfest sediment were due to longer experimental times. For both sediments, the VIP plots showed that current density and time after acidification was equally important for the removal of $\mathrm{Cu}, \mathrm{Pb}$ and $\mathrm{Zn}$ in the 2compartment as well as the 3-compartment cell.

The PLS models of the stack experiments had correlation factors, R2Y of 0.76-0.77 and predictive powers of 0.65-.070. Comparison between the two sediments was based on the same experimental domain. The VIP plots showed different trends for the two sediments. Time after acidification had the highest influence for removal of $\mathrm{Cu}, \mathrm{Pb}$ and $\mathrm{Zn}$ from the Hammerfest sediment, while current density had a larger impact on the removal in the 
Sisimiut sediment. The difference in variable importance between the two sediments could be due to the difference in the final $\mathrm{pH}$. $\mathrm{pH}$ decreased to 3.87 in the Hammerfest sediment suspension, while $\mathrm{pH}$ decreased to 3.15 in the Sisimiut sediment suspension within the same time frame. Relatively more desorption could occur at lower $\mathrm{pH}$ levels resulting in comparative larger influence of current density.

\subsubsection{Removal efficiencies and energy consumption}

Experiments conducted at the centre points of the continuous variables have the same experimental settings enabling direct comparison of removal efficiencies between the three set-ups. For the Hammerfest sediment, the remediation time (24 hours after acidification) was too short to detect any clear trends when comparing the three set-ups.

The experiments representing the centre of the continuous variables for the Sisimiut sediment had a remediation time after acidification of 163 hours. Figure 5 summarises the clean-up levels of $\mathrm{Cu}, \mathrm{Pb}$ and $\mathrm{Zn}$ for experiments 6, 7 (3-compartment cell), 14, 15 (2-cell compartment) and 22 (stack). The removal efficiencies are higher in the cell experiments indicating that the stack experiments need longer remediation times to reach similar clean-up levels. For the cell experiments more $\mathrm{Cu}$ is removed in the 2-compartment cell, while the clean-up levels of $\mathrm{Pb}$ and $\mathrm{Zn}$ are comparable.

\section{Figure 5}

In a previous study of polluted soil, energy consumption for the removal of $\mathrm{Cu}(0.1-0.2$ $\mathrm{mA} / \mathrm{cm}^{2} ; 240$ hours) in a 3-compartment cell set-up were in the range 0.1-3.2 Wh/mg Cu [25], which is comparable to the levels found in this study, listed in table 4. In the direct comparison of energy consumption, it is apparent that the lowest energy consumption for $\mathrm{Cu}$, $\mathrm{Pb}$ and $\mathrm{Zn}$ is found in the 2-compartment cell, while the highest levels, by a magnitude, are found in the stack. In all three set-ups relative higher amounts of Zn are removed per same energy consumption unit than the other heavy metals due to the higher mobility of Zn. 
Table 4: Energy consumption in the Sisimiut experiments

\begin{tabular}{|c|l|l|l|l|}
\hline \multicolumn{2}{|c|}{} & \multicolumn{3}{|c|}{ Energy consumption per removed $\mathrm{Cu} / \mathrm{Pb} / \mathrm{Zn} / \mathrm{mg})$} \\
\hline \multicolumn{3}{|c|}{ Experimental settings } \\
\hline \multirow{3}{*}{ 2-compartment cell } & $0.04 \mathrm{~mA} / \mathrm{cm}^{2}$ & $4.3 / 1.0 / 0.3$ & n.e & n.e \\
\cline { 2 - 5 } & $0.12 \mathrm{~mA} / \mathrm{cm}^{2}$ & n.e. & $0.2 / 0.4 / 0.1$ & n.e \\
\cline { 2 - 5 } & $0.20 \mathrm{~mA} / \mathrm{cm}^{2}$ & n.e & n.e & $10 / 18 / 5.3$ \\
\hline \multirow{3}{*}{3 -compartment cell } & $0.04 \mathrm{~mA} / \mathrm{cm}^{2}$ & n.e & n.e & $1.4 / 3.2 / 0.6$ \\
\cline { 2 - 5 } & $0.12 \mathrm{~mA} / \mathrm{cm}^{2}$ & n.e & $1.1 / 0.6 / 0.2$ & n.e \\
\cline { 2 - 5 } & $0.20 \mathrm{~mA} / \mathrm{cm}^{2}$ & $13 / 5.1 / 1.6$ & n.e & n.e \\
\hline \multirow{5}{*}{ Stack } & $0.04 \mathrm{~mA} / \mathrm{cm}^{2}$ & $1.8 / 0.2 / 0.5$ & n.e & $4.4 / 0.3 / 0.4$ \\
\cline { 2 - 5 } & $0.12 \mathrm{~mA} / \mathrm{cm}^{2}$ & n.e & $33 / 4.5 / 2.9$ & n.e \\
\cline { 2 - 5 } & $0.20 \mathrm{~mA} / \mathrm{cm}^{2}$ & $162 / 53 / 29$ & n.e & $73 / 85 / 18$ \\
\hline
\end{tabular}

n.e.: no experiment

For the 2-compartment and 3-compartment cell set-ups the lowest energy consumption is registered in the centre experiments $\left(0.12 \mathrm{~mA} / \mathrm{cm}^{2}, 163 \mathrm{~h}\right)$ which could be due to a more ideal current density, i.e. low resistance but current still mobilising/removing relatively higher amounts than in the low current density experiments. For the stack experiments the lowest energy consumption is registered for the low current density experiments indicating that higher current does not lead to relatively more removal of metals. A more thorough analysis of heavy metal removal in the stack is however necessary to investigate this trend.

\subsection{Stack experiments}

A previous study showed that EDR can be divided into four phases: a lag phase in which limited metal removal occurs; a fast metal removal phase in which the given metal is desorbed/dissolved; a slow metal removal phase in which metal related to lesser available fractions is desorbed/dissolved and finally a stationary phase [26]. In the Sisimiut sediment stack experiments $\mathrm{Cu}, \mathrm{Pb}$ and $\mathrm{Zn}$ appear to be in the lag phase of EDR [26] and limited mobilisation of the heavy metals occurs (figure 6). For the two experiments run at higher current densities, $\mathrm{Zn}$ is mobilised at a constant rate during the whole experiment indicating $\mathrm{Zn}$ being in the fast removal phase. At the end of the experiments run at a current density of $0.12 \mathrm{~mA} / \mathrm{cm}^{2}$, an increase in mobilisation of $\mathrm{Cu}$ and $\mathrm{Pb}$ occurs indicating the initiation of the fast metal removal phase. For the high current density experiments $\left(0.2 \mathrm{~mA} / \mathrm{cm}^{2}\right)$, faster 
desorption/dissolution of $\mathrm{Cu}$ and $\mathrm{Pb}$ begins after approximately 8 hours (experiment duration time after acidification). The results are in line with the findings of current density having a larger influence on EDR in the stack than time after acidification (model 6c).

Figure 6

The development in $\mathrm{pH}$ was similar in the three stack experiments (figure 7) both during and after acidification, so the difference in metal mobilisation must be due to the current density; and within the studied experimental domain a current density higher than $0.04 \mathrm{~mA} / \mathrm{cm}^{2}$ is necessary for significant mobilisation of the targeted heavy metals.

\section{Figure 7}

At the end of all three experiments it was observed that approximately $60 \%$ of the desorbed heavy metals were found in the sediment suspension liquid. In the sediment suspensions of the cell experiments of equivalent supplied electrical charge, approximately $30 \%$ of the mobilised heavy metals were found in the suspension liquid. For cell experiments conducted at lower remediation times, higher fractions of mobilised heavy metals were found in the suspension liquids. Accordingly, the reason for the high fractions of mobilised heavy metals in the sediment suspension of the stack could be due to terminating experiments while EDR was still in the fast removal phases, i.e. desorption/dissolution was still on-going, rather than due to the residence time of the sediment suspension in the stack. In addition, this is in line with a previous study of the EDR stack in which high fractions of mobilised heavy metals were also found in the suspension liquid [17].

\subsection{Scaling-up of lab-scale experiments}

The present study can serve as foundation for scaling-up EDR to enable treatment of larger quantities of sediment. Whilst it was found that the cell and stack set-ups were different and could not be directly compared, it is however possible to recognize traits important for the scaling-up. 
Sediments were found to have the highest influence on EDR and should be modelled separately. If sediment characteristics of larger data-sets were included, it is however possible that sediments could be modelled in the same model [23]. When these are not included, optimal remediation conditions for each sediment should be determined on lab-scale prior to proceeding with bench-scale. The cell experiments could be used for indicating of optimal current density for remediation. In this study it was for instance found that the optimal current density in relation to highest removal per consumed energy was $0.12 \mathrm{~mA} / \mathrm{cm}^{2}$ (centre value). The stack experiments indicate, that heavy metal desorption occurs at this current density as well and could therefore function as a good starting point for bench-scale experiments (although longer remediation times would be necessary).

The direct comparison of the same experimental settings in the three set-ups revealed higher removal efficacies of the targeted heavy metals, $\mathrm{Cu}, \mathrm{Pb}$ and $\mathrm{Zn}$, in the cell experiments than the stack experiments, indicating that relatively more electrical charge per mass unit is necessary in the stack. Remediation in the stack should hence be conducted at longer remediation times than applied in this study.

Higher energy consumption per removed heavy metal unit was observed in the stack. This could potentially be reduced by running the stack experiments at longer remediation times and by increasing the volume of sediment suspension. The latter might result in longer remediation times, but could also reduce the energy consumption per mg heavy metal removed. Energy consumption levels similar to the cell experiments should however not be expected.

\section{Conclusion}

Multivariate analysis revealed that the type of sediment highly influenced EDR results and each sediment should be modelled separately. In addition it was found that the three experimental set-ups should be considered as three different systems. Modelling the 
sediments and experimental set-ups separately showed that the current density and time after acidification was equally important for both sediments in the cell experiments. In the stack experiments, the importance of the two continuous variables varied between the two sediments due to difference in final $\mathrm{pH}$ and hence desorption of heavy metals in the sediments.

In the studied experimental domain, the optimal current density in the cell experiments with regards to removing the highest amount of $\mathrm{Cu}, \mathrm{Pb}$ and $\mathrm{Zn}$ per Wh was $0.12 \mathrm{~mA} / \mathrm{cm}^{2}$ (centre value). The highest percentages of metals removed, $82 \% \mathrm{Cu}, 81 \% \mathrm{~Pb}$ and $92 \% \mathrm{Zn}$, were however achieved at higher current density. Maintaining the optimal current density would hence entail operating at higher remediation times to achieve similar removal efficiencies. For the comparable stack experiments the energy consumption was an order of magnitude higher and the highest clean-up levels were still only $21 \% \mathrm{Cu}, 42 \% \mathrm{~Pb}$ and $73 \% \mathrm{Zn}$. In order to improve the removal efficiencies longer remediation times in the stack experiments are necessary.

\section{Acknowledgements}

The Northern Environmental Waste Management (EWMA) project, which is funded by the Research Council of Norway through NORDSATSNING (grant number 195160) and Eni Norge AS, is acknowledged for funding. Hammerfest municipality is acknowledged for providing boat and assistance in sampling of sediments in Hammerfest. Tore Lejon and Kristine B. Pedersen acknowledge The Arctic Technology Centre at DTU for funding the trip to Greenland and in addition the technical staff is acknowledged for assistance with sampling and sediment analyses.

\section{References}

[1] Y.B. Acar, A.N. Alshawabkeh, R.J. Gale, Waste Manage, 13 (1993) 141-151.

[2] Y.B. Acar, A.N. Alshawabkeh, Environ Sci Technol, 27 (1993) 2638-+.

[3] Y.B. Acar, R.J. Gale, A.N. Alshawabkeh, R.E. Marks, S. Puppala, M. Bricka, R. Parker, J Hazard Mater, 40 (1995) 117-137. 
[4] A.N. Alshawabkeh, Separ Sci Technol, 44 (2009) 2171-2187.

[5] L.M. Ottosen, H.K. Hansen, C.B. Hansen, J Appl Electrochem, 30 (2000) 1199-1207.

[6] L.M. Ottosen, I.V. Kristensen, A.J. Pedersen, H.K. Hansen, A. Villumsem, A.B. Ribeiro, Separ Sci Technol, 38 (2003) 1269-1289.

[7] P.E. Jensen, B.K. Ahring, L.M. Ottosen, J Chem Technol Biot, 82 (2007) 920-928.

[8] A.B. Ribeiro, E.P. Mateus, L.M. Ottosen, G. Bech-Nielsen, Environ Sci Technol, 34 (2000) 784-788.

[9] A.J. Pedersen, L.M. Ottosen, A. Villumsen, J Hazard Mater, 122 (2005) 103-109.

[10] G.M. Nystroem, L.M. Ottosen, A. Villumsen, Environ Sci Technol, 39 (2005) 2906-2911.

[11] G.M. Nystrom, L.M. Ottosen, A. Villumsen, Eng Geol, 77 (2005) 349-357.

[12] P.E. Jensen, L.M. Ottosen, C. Ferreira, Electrochim Acta, 52 (2007) 3412-3419.

[13] L.M. Ottosen, P.E. Jensen, G.M. Kirkelund, C.D. Ferreira, H.K. Hansen, Chemical Engineering Transactions, 28 (2012) 103-108.

[14] G.M. Kirkelund, L.M. Ottosen, A. Villumsen, J Hazard Mater, 169 (2009) 685-690.

[15] A.J. Pedersen, L.M. Ottosen, A. Villumsen, J Hazard Mater, 100 (2003) 65-78.

[16] B. Ebbers, L.M. Ottosen, P.E. Jensen, Chemosphere, (Submitted).

[17] P.E. Jensen, C.M.D. Ferreira, H.K. Hansen, J.U. Rype, L.M. Ottosen, A. Villumsen, J Appl

Electrochem, 40 (2010) 1173-1181.

[18] G.M. Kirkelund, P.E. Jensen, A. Villumsen, L.M. Ottosen, J Appl Electrochem, 40 (2010) 10491060.

[19] R. Carlson, J.E. Carlson, Design and Optimisation in Organic Synthesis, Second ed., Elsevier, Amsterdam, The Netherlands, 2005.

[20] S. Wold, M. Sjöström, L. Eriksson, Chemometrics and Intelligent Laboratory Systems, 58 (2001) 109-130.

[21] J. Trygg, S. Wold, Journal of Chemometrics, 16 (2002) 119-128.

[22] K.B. Pedersen, T. Lejon, L.M. Ottosen, P.E. Jensen, Environ Technol, (Submitted).

[23] K.B. Pedersen, G.M. Kirkelund, L.M. Ottosen, P.E. Jensen, T. Lejon, J Hazard Mater, 283 (2015) 712-720.

[24] G. Rauret, J.F. Lopez-Sanchez, A. Sahuquillo, R. Rubio, C. Davidson, P. Quevauviller, J Environ Monitor, 1 (1999) 57-61.

[25] T.R. Sun, L.M. Ottosen, Electrochim Acta, 86 (2012) 28-35.

[26] P.E. Jensen, L.M. Ottosen, C. Ferreira, A. Villumsen, J Hazard Mater, 138 (2006) 493-499. 


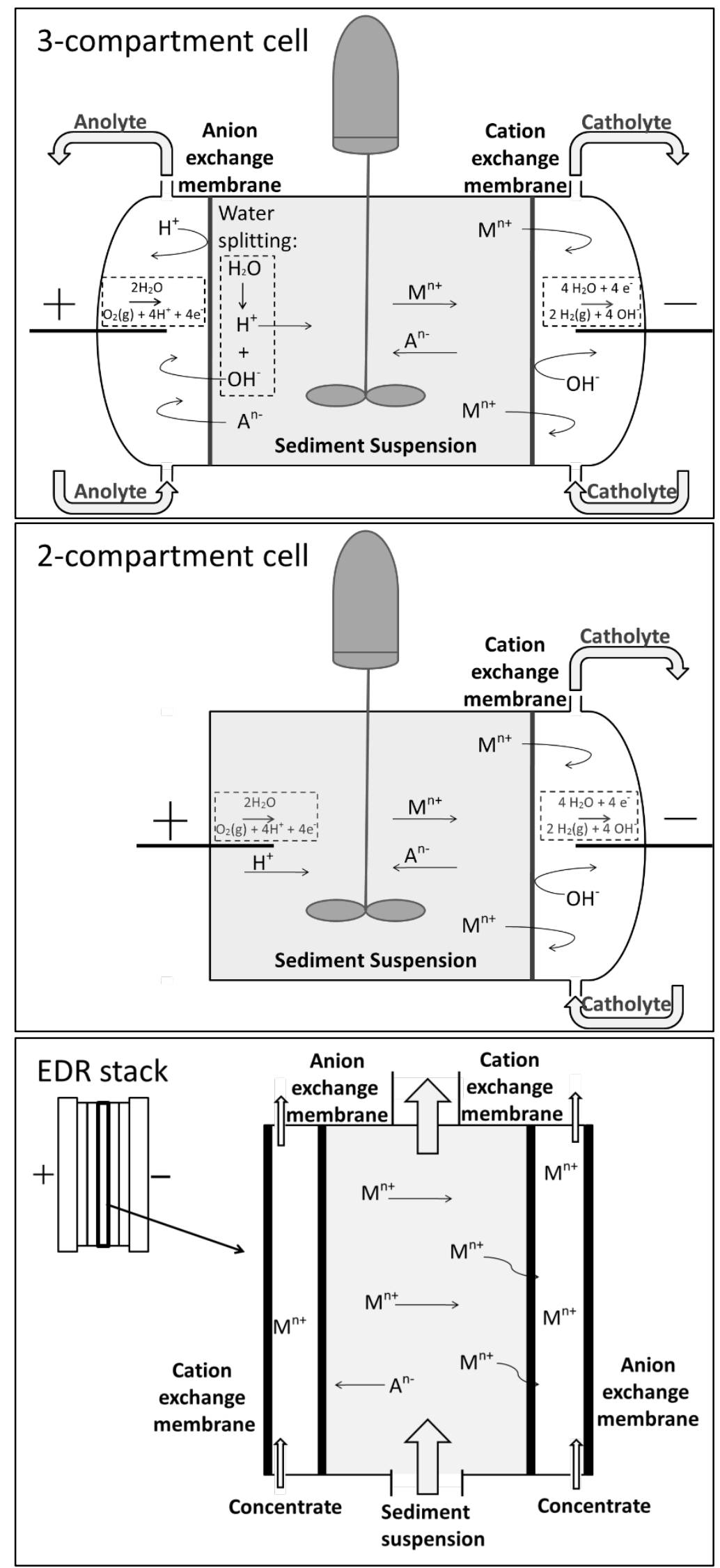

Figure 1: The EDR cell and stack designs: 3-compartment cell, 2-compartment cell and stack. 


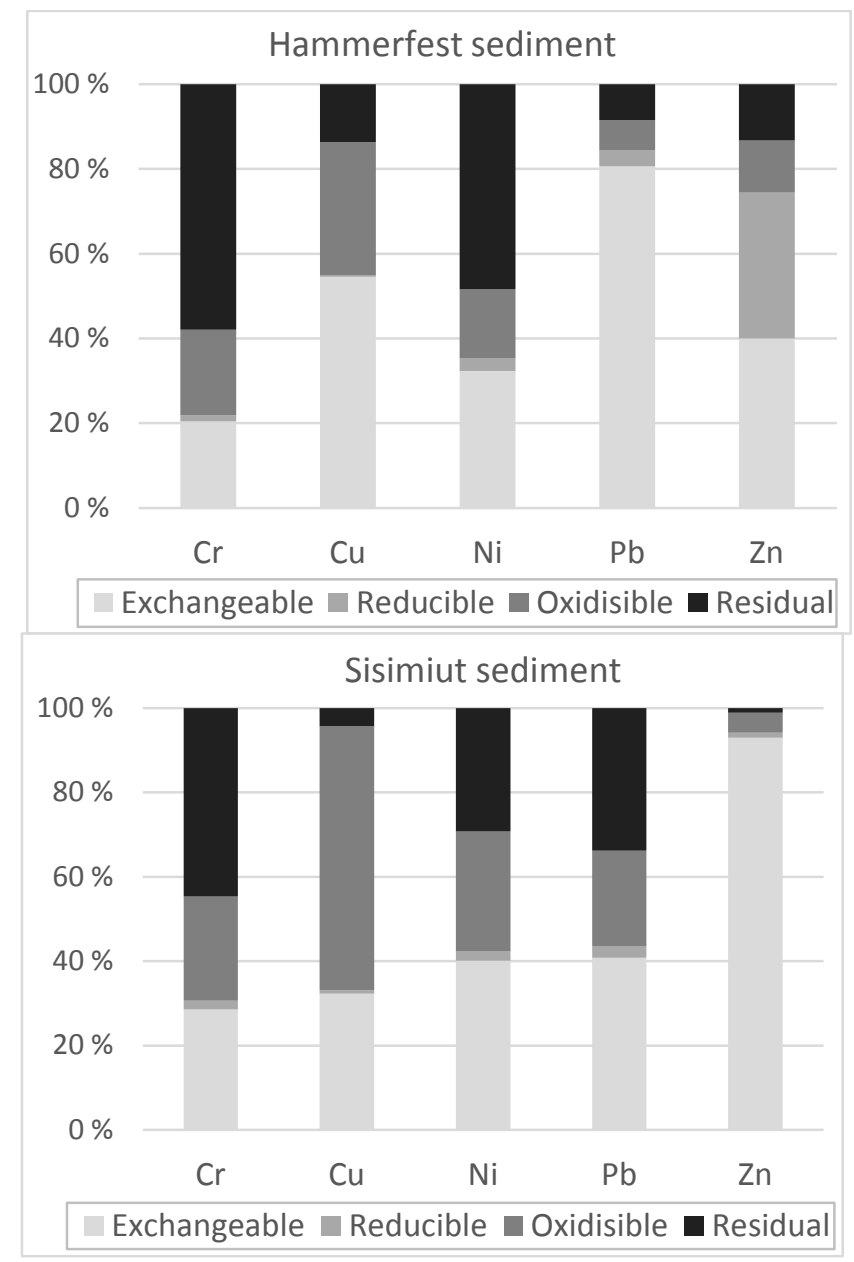

Figure 2: Distribution of heavy metals in the different fractions of the sediments.

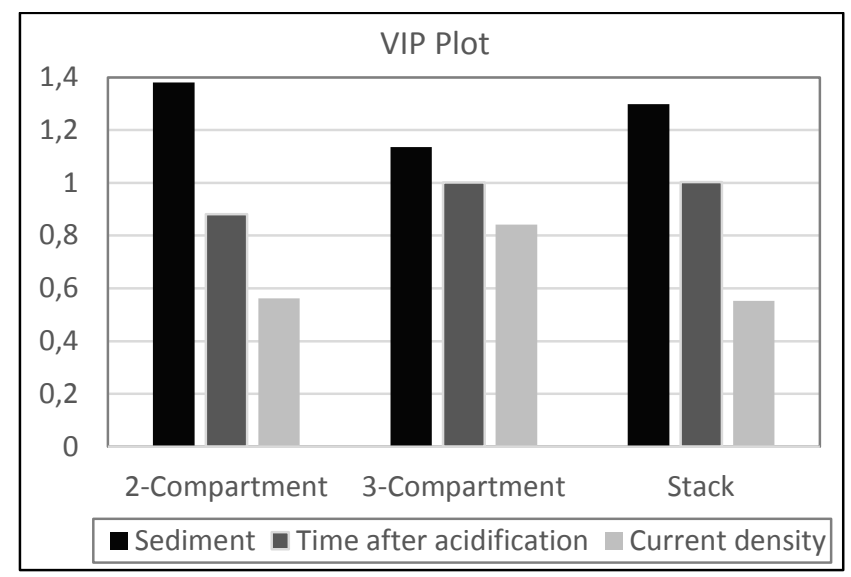

Figure 3: Summary of VIP plots of removal efficacies in the 3-compartment cell (model 1a), 2-compartment cell (model 1b) and EDR stack (model 1c). Highest VIP values indicate highest influence on EDR. 


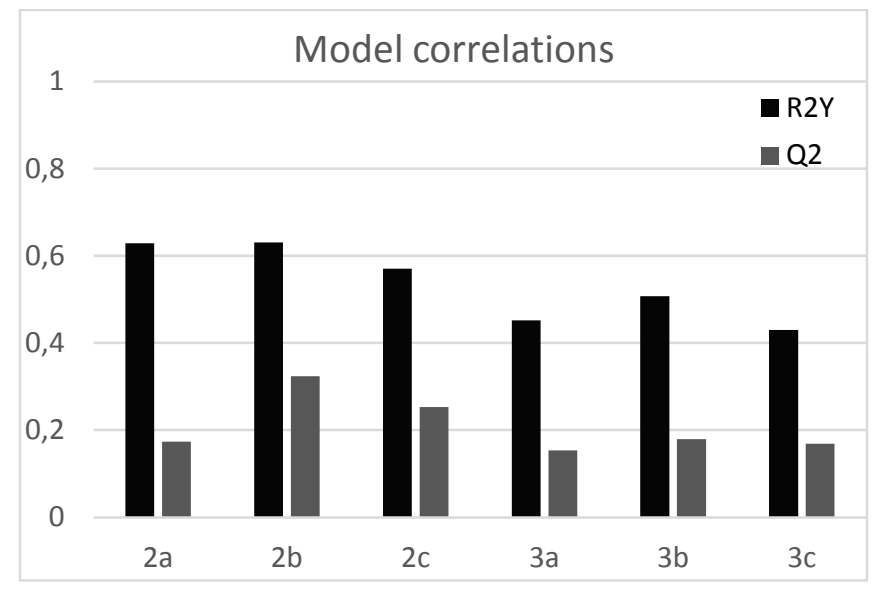

Figure 4: Model correlation factors, R2Y, and predictive powers, Q2, of the set-up comparisons for the Hammerfest (models 2a-2c) and Sisimiut (models 3a-3c) sediments.

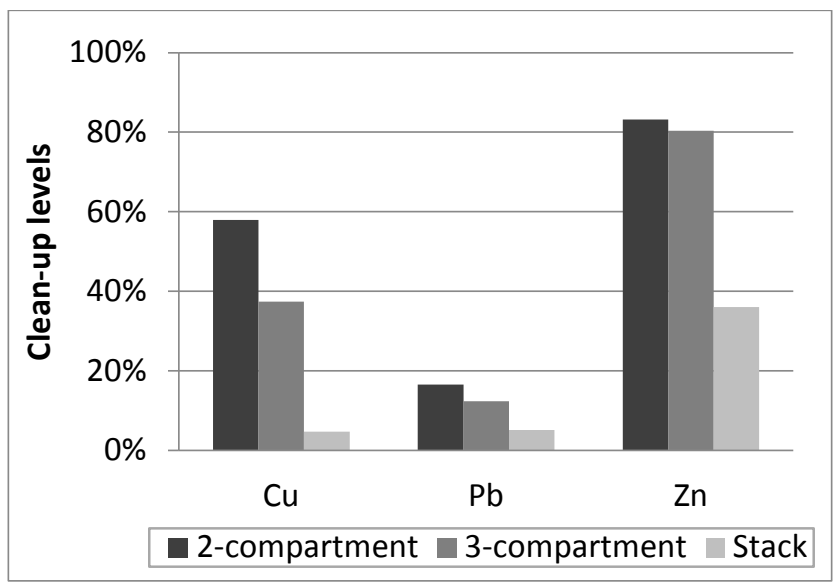

Figure 5: Clean-up levels of $\mathrm{Cu}, \mathrm{Pb}$ and $\mathrm{Zn}$ in the three experimental set-ups in centre experiments. The 2-compartment cell experiments were replicated and the average deviations were $14 \%$ for $\mathrm{Cu}, 3 \%$ for $\mathrm{Pb}$ and $1 \%$ for $\mathrm{Zn}$. 


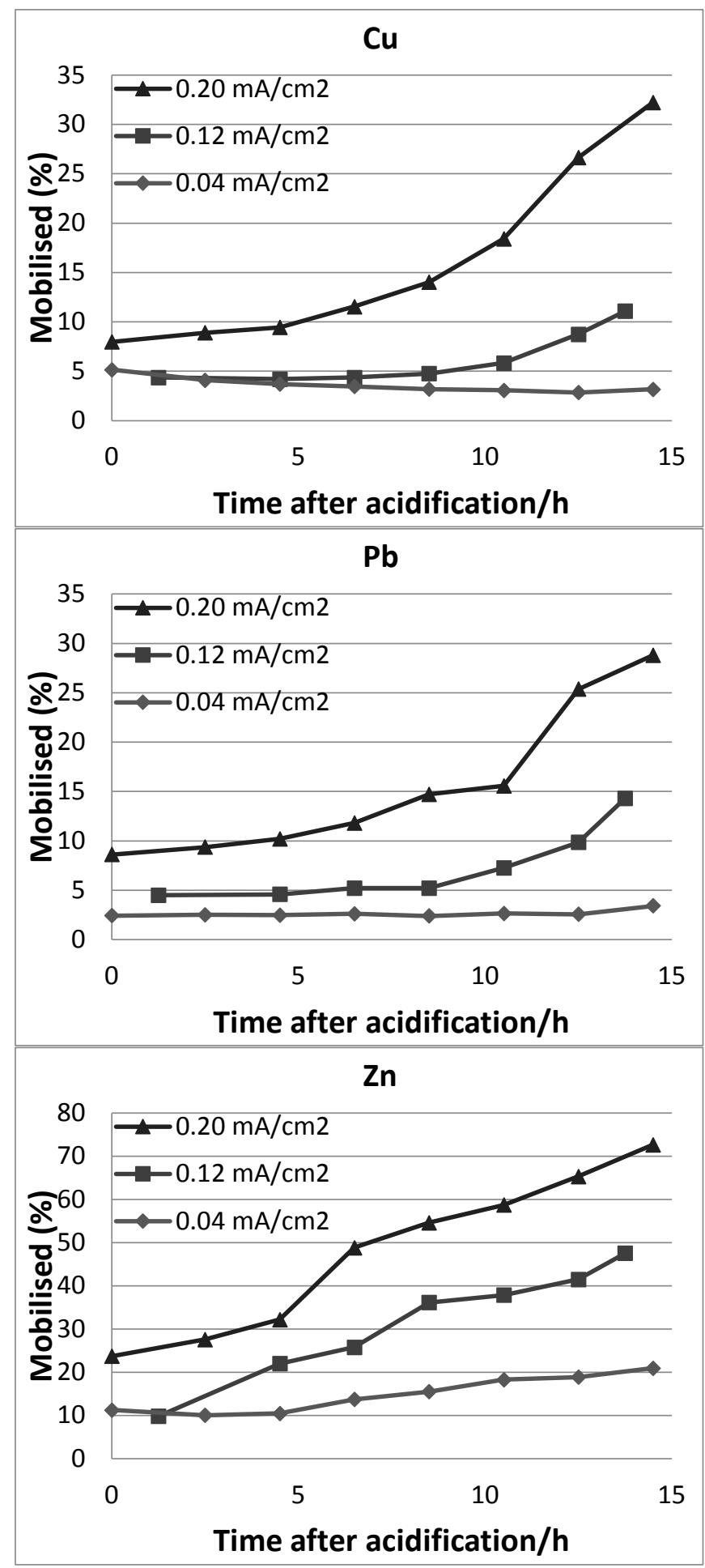

Figure 6: Mobilised $\mathrm{Cu}, \mathrm{Pb}$ and $\mathrm{Zn} \mathrm{( \% )} \mathrm{at} \mathrm{different} \mathrm{current} \mathrm{densities} \mathrm{in} \mathrm{the} \mathrm{EDR} \mathrm{stack}$ as function of remediation time after acidification. 


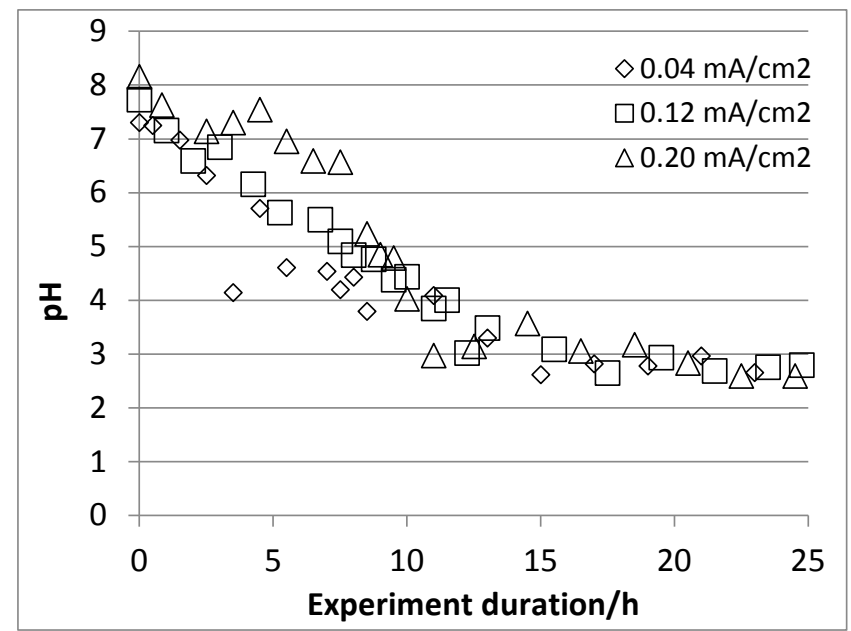

Figure 7: Development in $\mathrm{pH}$ as a function of experiment duration time during EDR stack experiments of the Sisimiut sediment. 
Table A: Results of EDR experiments of the Hammerfest sediment

\begin{tabular}{|c|c|c|c|c|c|c|c|c|c|c|c|c|c|c|c|c|}
\hline & \multicolumn{5}{|c|}{ 3-compartment cell } & \multicolumn{7}{|c|}{ 2-compartment cell } & \multicolumn{4}{|c|}{ Stack } \\
\hline $\begin{array}{l}\text { Experime } \\
\mathrm{nt}\end{array}$ & 1 & 4 & 5 & 23 & 26 & 9 & 10 & 12 & 13 & 24 & 25 & 27 & 16 & 17 & 20 & 21 \\
\hline $\begin{array}{l}\text { Acidificati } \\
\text { on time } \\
\text { (h) }\end{array}$ & 33 & 31 & 25 & 25 & 31 & 5 & 7 & 23 & 20 & 26 & 17 & 22 & 15 & 16 & 15 & 15 \\
\hline $\begin{array}{l}\text { Electric } \\
\text { charge for } \\
\text { acidificati } \\
\text { on (C/g } \\
\text { sediment) }\end{array}$ & 3.2 & 15 & 5.6 & 12 & 8.9 & 2.4 & 0.7 & 6.6 & 5.6 & 2.5 & 8.2 & 6.3 & 11 & 51 & 31 & 31 \\
\hline Initial pH & 7.5 & 7.5 & 7.5 & 7.5 & 7.5 & 7.5 & 7.5 & 7.5 & 7.5 & 7.5 & 7.5 & 7.5 & 7.5 & 7.5 & 7.5 & 7.5 \\
\hline Final pH & 2.4 & 3.7 & 2.0 & 3.8 & 2.5 & 2.8 & 2.0 & 1.5 & 1.8 & 2.3 & 4.0 & 2.5 & 4.0 & 3.9 & 3.4 & 3.5 \\
\hline $\begin{array}{l}\text { Energy } \\
\text { consumpti } \\
\text { on } \\
\text { (kWh/kg } \\
\text { sediment) }\end{array}$ & $\begin{array}{l}0.0 \\
2\end{array}$ & $\begin{array}{l}0.7 \\
8\end{array}$ & $\begin{array}{l}0.0 \\
3\end{array}$ & $\begin{array}{l}0.0 \\
1\end{array}$ & $\begin{array}{l}0.0 \\
1\end{array}$ & $\begin{array}{l}0.0 \\
2\end{array}$ & $\begin{array}{l}0.0 \\
2\end{array}$ & $\begin{array}{l}0.0 \\
5\end{array}$ & $\begin{array}{l}0.0 \\
5\end{array}$ & $\begin{array}{l}0.00 \\
5\end{array}$ & $\begin{array}{l}0.0 \\
2\end{array}$ & $\begin{array}{l}0.0 \\
1\end{array}$ & $\begin{array}{l}0.0 \\
1\end{array}$ & $\begin{array}{l}0.6 \\
0\end{array}$ & $\begin{array}{l}0.0 \\
3\end{array}$ & $\begin{array}{l}0.0 \\
2\end{array}$ \\
\hline \multicolumn{17}{|c|}{ Recovery of metals (\%) } \\
\hline $\mathrm{Cr}$ & 68 & 85 & 76 & 75 & 63 & $\begin{array}{r}11 \\
4 \\
\end{array}$ & 96 & $\begin{array}{r}10 \\
8\end{array}$ & 88 & 109 & $\begin{array}{r}11 \\
1 \\
\end{array}$ & $\begin{array}{r}10 \\
7 \\
\end{array}$ & $\begin{array}{l}11 \\
0\end{array}$ & 63 & 87 & 60 \\
\hline $\mathrm{Cu}$ & 94 & 78 & 93 & $\begin{array}{r}12 \\
0\end{array}$ & 84 & $\begin{array}{r}11 \\
3 \\
\end{array}$ & $\begin{array}{r}10 \\
1 \\
\end{array}$ & $\begin{array}{r}12 \\
1\end{array}$ & $\begin{array}{r}10 \\
5\end{array}$ & 114 & $\begin{array}{r}10 \\
9 \\
\end{array}$ & $\begin{array}{r}11 \\
6 \\
\end{array}$ & $\begin{array}{l}10 \\
5 \\
\end{array}$ & $\begin{array}{l}11 \\
5\end{array}$ & $\begin{array}{l}11 \\
0\end{array}$ & 85 \\
\hline $\mathrm{Ni}$ & 72 & 91 & 97 & 73 & 69 & $\begin{array}{r}12 \\
0\end{array}$ & $\begin{array}{r}11 \\
3\end{array}$ & $\begin{array}{r}13 \\
3 \\
\end{array}$ & $\begin{array}{r}12 \\
2\end{array}$ & 131 & $\begin{array}{r}12 \\
5 \\
\end{array}$ & $\begin{array}{r}11 \\
6 \\
\end{array}$ & $\begin{array}{l}11 \\
5\end{array}$ & 75 & 90 & 70 \\
\hline $\mathrm{Pb}$ & 62 & 90 & 77 & 72 & 59 & $\begin{array}{r}11 \\
1\end{array}$ & $\begin{array}{r}10 \\
4\end{array}$ & $\begin{array}{r}11 \\
3\end{array}$ & $\begin{array}{r}10 \\
0\end{array}$ & 122 & $\begin{array}{r}11 \\
2\end{array}$ & $\begin{array}{r}11 \\
4\end{array}$ & $\begin{array}{l}12 \\
3\end{array}$ & $\begin{array}{l}12 \\
0\end{array}$ & 85 & 66 \\
\hline Zn & $\begin{array}{r}10 \\
5 \\
\end{array}$ & $\begin{array}{r}10 \\
8 \\
\end{array}$ & 99 & 91 & 89 & $\begin{array}{r}12 \\
0 \\
\end{array}$ & $\begin{array}{r}10 \\
2 \\
\end{array}$ & $\begin{array}{r}13 \\
5 \\
\end{array}$ & $\begin{array}{r}11 \\
3 \\
\end{array}$ & 133 & $\begin{array}{r}11 \\
7 \\
\end{array}$ & $\begin{array}{r}11 \\
5 \\
\end{array}$ & $\begin{array}{l}12 \\
5 \\
\end{array}$ & $\begin{array}{l}13 \\
0 \\
\end{array}$ & 99 & 90 \\
\hline Removal ef & cienc & es $(\%$ & & & & & & & & & & & & & & \\
\hline $\mathrm{Cr}$ & 34 & 12 & 34 & 25 & 34 & 0 & 14 & 12 & 27 & 0 & 0 & 0 & 0.2 & 0 & 23 & 37 \\
\hline $\mathrm{Cu}$ & 44 & 63 & 68 & 0 & 31 & 34 & 62 & 65 & 67 & 9 & 0 & 0 & 0 & 48 & 44 & 46 \\
\hline $\mathrm{Ni}$ & 34 & 22 & 42 & 24 & 33 & 6 & 23 & 26 & 32 & 0 & 0 & 0 & 0 & 34 & 19 & 15 \\
\hline $\mathrm{Pb}$ & 58 & 64 & 79 & 24 & 49 & 32 & 44 & 79 & 78 & 3 & 0 & 0 & 0 & 59 & 15 & 17 \\
\hline $\mathrm{Zn}$ & 68 & 64 & 71 & 32 & 59 & 48 & 63 & 59 & 72 & 40 & 0 & 37 & 0 & 42 & 25 & 20 \\
\hline
\end{tabular}


Table B: Results of EDR experiments of the Sisimiut sediment

\begin{tabular}{|c|c|c|c|c|c|c|c|c|c|c|}
\hline & \multicolumn{3}{|c|}{$\begin{array}{c}\text { 3-compartment } \\
\text { cell }\end{array}$} & \multicolumn{4}{|c|}{ 2-compartment cell } & \multicolumn{3}{|c|}{ Stack } \\
\hline Experiment & 2 & 3 & 7 & 8 & 11 & 14 & 15 & 18 & 19 & 22 \\
\hline Acidification time (h) & 23 & 31 & 26 & 31 & 22 & 31 & 23 & 9 & 12 & 10 \\
\hline $\begin{array}{l}\text { Electric charge for } \\
\text { acidification (C/g } \\
\text { sediment) }\end{array}$ & 11 & 3.0 & 7.5 & 3.0 & 10 & 8.8 & 6.6 & 6 & 32 & 21 \\
\hline Initial pH & 7.5 & 7.5 & 7.5 & 7.5 & 7.5 & 7.5 & 7.5 & 7.5 & 7.5 & 7.5 \\
\hline Final pH & 2.4 & 1.8 & 2.7 & 3.2 & 1.8 & 2.4 & 2.3 & 3.8 & 2.9 & 2.6 \\
\hline $\begin{array}{l}\text { Energy consumption } \\
\text { (kWh/kg sediment) }\end{array}$ & 0.03 & 0.01 & 0.04 & 0.01 & 0.18 & 0.03 & 0.03 & 0.03 & 0.28 & 1.23 \\
\hline \multicolumn{11}{|l|}{ Recovery of metals (\%) } \\
\hline $\mathrm{Cr}$ & 90 & 101 & 87 & 87 & 89 & 86 & 119 & 107 & 88 & 100 \\
\hline $\mathrm{Cu}$ & 116 & 92 & 84 & 91 & 92 & 125 & 80 & 128 & 101 & 114 \\
\hline $\mathrm{Ni}$ & 105 & 126 & 115 & 105 & 122 & 77 & 92 & 105 & 78 & 125 \\
\hline $\mathrm{Pb}$ & 122 & 111 & 115 & 123 & 99 & 100 & 114 & 102 & 110 & 113 \\
\hline $\mathrm{Zn}$ & 120 & 120 & 120 & 112 & 117 & 99 & 101 & 115 & 111 & 107 \\
\hline \multicolumn{11}{|c|}{ Removal efficiencies (\%) } \\
\hline $\mathrm{Cr}$ & 14 & 9 & 2 & 9 & 32 & 33 & 2 & 0 & 5 & 2 \\
\hline $\mathrm{Cu}$ & 9 & 45 & 37 & 12 & 82 & 50 & 66 & 0 & 33 & 5 \\
\hline $\mathrm{Ni}$ & 27 & 25 & 36 & 20 & 40 & 16 & 34 & 0 & 27 & 16 \\
\hline $\mathrm{Pb}$ & 0 & 36 & 12 & 2 & 49 & 17 & 16 & 0 & 30 & 5 \\
\hline $\mathrm{Zn}$ & 73 & 84 & 80 & 62 & 92 & 82 & 84 & 0 & 73 & 41 \\
\hline
\end{tabular}

